\title{
Effect of zirconia addition on the oxidation resistance of Ni-toughened $\mathrm{Al}_{2} \mathrm{O}_{3}$
}

\author{
T.C. Wang, R.Z. Chen, W.H. Tuan* \\ Institute of Materials Science and Engineering, National Taiwan University, Taipei, Taiwan 106, ROC
}

Received 8 July 2002; received in revised form 20 April 2003; accepted 27 April 2003

\begin{abstract}
The incorporation of equal amount of $\mathrm{Ni}$ and $\mathrm{ZrO}_{2}$ particles can significantly enhance the toughness of $\mathrm{Al}_{2} \mathrm{O}_{3}$. In the present study, the oxidation resistance of $\mathrm{Al}_{2} \mathrm{O}_{3} / \mathrm{ZrO}_{2} / \mathrm{Ni}$ composites at $1200{ }^{\circ} \mathrm{C}$ for up to $400 \mathrm{~h}$ is evaluated. The presence of $\mathrm{ZrO}_{2}$ particles accelerates the oxidation of $\mathrm{Ni}$ particles in the $\mathrm{Al}_{2} \mathrm{O}_{3}$ matrix. Furthermore, the oxidation rate constant of the composites increases significantly when the $\mathrm{ZrO}_{2}$ addition is higher than 10 vol.\%, the threshold at which that $\mathrm{ZrO}_{2}$ inclusions form continuous networks. The effect of the polymorphic form of $\mathrm{ZrO}_{2}$ on the oxidation resistance is also evaluated. The oxidation resistance of $\mathrm{Al}_{2} \mathrm{O}_{3} /$ $\mathrm{m}-\mathrm{ZrO}_{2} / \mathrm{Ni}$ composites is slightly better than that of $\mathrm{Al}_{2} \mathrm{O}_{3} / \mathrm{t}-\mathrm{ZrO}_{2} / \mathrm{Ni}$ composites.

(C) 2003 Elsevier Ltd. All rights reserved.
\end{abstract}

Keywords: $\mathrm{Al}_{2} \mathrm{O}_{3}$; Composites; Metallic inclusions; Oxidation; $\mathrm{ZrO}_{2}$

\section{Introduction}

The applications of monolithic ceramics are frequently limited by their brittleness. To improve the toughness of ceramics, toughening agents, either ceramic or metallic particles, are incorporated into ceramic matrices to interact with the propagating crack. The metals are relatively ductile in nature; they can deform plastically during the opening of crack surfaces and consequently enhance the toughness. Among the metals investigated, nickel has attracted the most attention. The Ni-toughened $\mathrm{Al}_{2} \mathrm{O}_{3}$ can be prepared by pressureless sintering; furthermore, their strength and toughness can reach two to three times that of alumina alone. ${ }^{1-3}$ However, the natural oxidation resistance of alumina is degraded due to the addition of $\mathrm{Ni}$ particles. A recent study on the oxidation of Ni-toughened $\mathrm{Al}_{2} \mathrm{O}_{3}$ demonstrated that a dense nickel aluminate spinel, $\mathrm{NiAl}_{2} \mathrm{O}_{4}$, is formed on the surface after oxidation at elevated temperature. ${ }^{4}$ The oxidation process of the Ni-toughened $\mathrm{Al}_{2} \mathrm{O}_{3}$ involves diffusion. Due to the slow diffusion of oxygen through the alumina and spinel; the $\mathrm{Ni}$ inclusions are well protected by the surrounding matrix.

\footnotetext{
* Corresponding author. Tel.: + 886-2-2365-9800; fax: + 886-22363-4562.

E-mail address: tuan@ccms.ntu.edu.tw (W.H. Tuan).
}

The toughness of Ni-toughened $\mathrm{Al}_{2} \mathrm{O}_{3}$ can be further enhanced by adding $\mathrm{t}-\mathrm{ZrO}_{2}$ inclusions. ${ }^{5}$ The plastic deformation of $\mathrm{Ni}$ and the phase transformation of $\mathrm{t}-\mathrm{ZrO}_{2}$ can all take place during the fracturing of $\mathrm{Al}_{2} \mathrm{O}_{3} /$ $\mathrm{ZrO}_{2} / \mathrm{Ni}$ composites. Furthermore, two toughening mechanisms can interact with each other to bring in extra toughness enhancement, especially when the amount of $\mathrm{Ni}$ and $\mathrm{ZrO}_{2}$ is close to each other. ${ }^{6}$

Zirconia is a good oxygen conductor, the presence of $\mathrm{ZrO}_{2}$ inclusions may accelerate the oxidation of $\mathrm{Ni}$ particles in the $\mathrm{Al}_{2} \mathrm{O}_{3}$ matrix. In order to determine the thermal stability of the $\mathrm{Al}_{2} \mathrm{O}_{3} / \mathrm{ZrO}_{2} / \mathrm{Ni}$ composites, the oxidation behavior of the composites is investigated in the present study. Furthermore, $\mathrm{ZrO}_{2}$ has three crystallographic forms, monoclinic $(\mathrm{m})$, tetragonal $(\mathrm{t})$ and cubic for $\mathrm{ZrO}_{2}$. Adding either $\mathrm{m}-\mathrm{ZrO} \mathrm{r}_{2}$ or $\mathrm{t}-\mathrm{ZrO}_{2}$ phase can enhance the toughness of ceramics; $;^{7,8}$ the effect of crystallographic phases of $\mathrm{ZrO}_{2}$ on the oxidation behavior is thus also investigated in the present study.

\section{Experimental procedures}

In the present study, $\mathrm{Al}_{2} \mathrm{O}_{3} / \mathrm{t}-\mathrm{ZrO}_{2} / \mathrm{Ni}$ and $\mathrm{Al}_{2} \mathrm{O}_{3} /$ $\mathrm{m}-\mathrm{ZrO}_{2} / \mathrm{Ni}$ composites were prepared by using a conventional powder mixing and pressureless sintering technique. The $\mathrm{Al}_{2} \mathrm{O}_{3} / \mathrm{Ni}$ composites were also prepared with the same technique for comparison purpose. 
An alumina powder (TM-DAR, specific surface area $=13.8 \mathrm{~m}^{2} / \mathrm{g}$, Taimei Chem. Co. Ltd., Japan) was ball-milled together with various amounts of zirconia powder ( $\mathrm{t}-\mathrm{ZrO}_{2}, \mathrm{ZrO}_{2}+3 \mathrm{~mol} \% \mathrm{Y}_{2} \mathrm{O}_{3}$, specific surface area $=14 \mathrm{~m}^{2} / \mathrm{g}$ or $\mathrm{m}-\mathrm{ZrO}_{2}, \mathrm{ZrO}_{2}+0 \mathrm{~mol} \% \mathrm{Y}_{2} \mathrm{O}_{3}$, specific surface area $=24 \mathrm{~m}^{2} / \mathrm{g}$, Hanwha Ceramics Co., Australia) and nickel oxide (NiO, mean particle size $=16 \mu \mathrm{m}$, Johnson Matthey Co., USA) powder in ethyl alcohol for $24 \mathrm{~h}$. The grinding media used were zirconia balls. The slurry of the powder mixture was dried with a rotary evaporator. The dried lumps were crushed and passed through a plastic sieve. Powder compacts of $7 \times 6 \times 50 \mathrm{~mm}$ were formed by pressing uniaxially at $44 \mathrm{MPa}$. The sintering was carried out in a box furnace at $1600{ }^{\circ} \mathrm{C}$ for $1 \mathrm{~h}$ in air. Both the heating rate and cooling rate were $5{ }^{\circ} \mathrm{C} / \mathrm{min}$. The green compacts were placed within a covered graphite crucible. A reducing atmosphere, carbon monoxide, was generated during sintering. The nickel oxide particles were reduced to result in nickel inclusions during sintering. The compositions investigated in the present study are shown in Table 1 . The final density of the specimens was determined by the Archimedes method. The solubility between the materials used in the present study was low; the relative density of the sintered composites was estimated by using the theoretical density of $3980 \mathrm{~kg} / \mathrm{m}^{3}$ for $\mathrm{Al}_{2} \mathrm{O}_{3}, 6100 \mathrm{~kg} / \mathrm{m}^{3}$ for $\mathrm{t}-\mathrm{ZrO}_{2}, 5830 \mathrm{~kg} / \mathrm{m}^{3}$ for $\mathrm{m}-\mathrm{ZrO}_{2}$ and $8900 \mathrm{~kg} / \mathrm{m}^{3}$ for Ni. The polished specimens were thermally etched at $1500{ }^{\circ} \mathrm{C}$ for $0.5 \mathrm{~h}$ to reveal the grain boundaries of matrix grains.

Microstructural characterization was performed by scanning electron microscopy (SEM). The atomic distribution within the oxidized specimens was characterized using electron dispersive X-ray spectroscopy (EDX). The interconnectivity of nickel particles within the $\mathrm{Al}_{2} \mathrm{O}_{3}$ matrix was determined by measuring the electrical resistance. The volume fraction of $\mathrm{Ni}$ after sintering was determined from the area fraction of nickel in SEM micrographs. To ensure the accuracy of the measurement, more than five SEM micrographs for each composition were used. The size of $\mathrm{Al}_{2} \mathrm{O}_{3}$ grains, $\mathrm{ZrO}_{2}$ and $\mathrm{Ni}$ inclusions was determined by using the line intercept technique. More than $300 \mathrm{Al}_{2} \mathrm{O}_{3}$ grains, 200 $\mathrm{ZrO}_{2}$ and $200 \mathrm{Ni}$ inclusions were counted.

The sintered specimens were machined longitudinally with a 325 grit resin-bonded diamond wheel at a depth of $5 \mu \mathrm{m} /$ pass. The final dimensions of the specimens were $3 \times 4 \times>36 \mathrm{~mm}$. The fracture toughness was determined by the single-edge-notched-beam (SENB) technique at ambient conditions. The rate of loading was 0.5 $\mathrm{mm} / \mathrm{min}$. The notch was generated by cutting with a diamond saw. The width of the notch was approximately $0.3 \mathrm{~mm}$. No annealing treatment was applied to the notched specimen before the toughness measurement. Five to eight specimens were used to determine the toughness for each composition.

The specimens for oxidation test were prepared by cutting the SENB bars into small rectangular specimens of $3 \times 4 \times 10 \mathrm{~mm}$. The specimens were submerged in an ultrasonic bath of acetone for $5 \mathrm{~min}$, and then dried in an oven at $120{ }^{\circ} \mathrm{C}$ for $3 \mathrm{~h}$. The dried specimens were cooled slowly in a vacuum chamber $\left(10^{-2}\right.$ torr $)$ to room temperature prior to weight measurement. The oxidation was carried out in a box furnace at $1200{ }^{\circ} \mathrm{C}$ for up to $400 \mathrm{~h}$. The heating rate of the oxidation test was $10{ }^{\circ} \mathrm{C} / \mathrm{min}$. After the specimen was oxidized for a certain time, the specimen was cooled down to a temperature of around $200{ }^{\circ} \mathrm{C}$ at a rate of $10{ }^{\circ} \mathrm{C} / \mathrm{min}$, then drawn from the furnace and placed into a vacuum chamber until it reached room temperature. Each

Table 1

The nickel content after sintering, relative density, size of matrix grains and inclusions for $\mathrm{Al}_{2} \mathrm{O}_{3} / \mathrm{Ni}, \mathrm{Al}_{2} \mathrm{O}_{3} / \mathrm{t}-\mathrm{ZrO}_{2} / \mathrm{Ni}$ and $\mathrm{Al} \mathrm{O}_{3} / \mathrm{m}-\mathrm{ZrO} \mathrm{O}_{2} / \mathrm{Ni}$ composites

\begin{tabular}{|c|c|c|c|c|c|}
\hline Added inclusion content $/$ vol. $\%$ & $\begin{array}{l}\text { Nickel content } \\
\text { after sintering/vol. \% }\end{array}$ & $\begin{array}{l}\text { Relative } \\
\text { density } / \%\end{array}$ & $\begin{array}{l}\mathrm{Al}_{2} \mathrm{O}_{3} \text { matrix } \\
\text { grains } / \mu \mathrm{m}\end{array}$ & $\mathrm{Ni}$ inclusions $/ \mu \mathrm{m}$ & $\begin{array}{l}\mathrm{ZrO}_{2} \\
\text { inclusions } / \mu \mathrm{m}\end{array}$ \\
\hline $\mathrm{Al}_{2} \mathrm{O}_{3}$ & 0 & 98.2 & 10.9 & - & - \\
\hline 5 vol. $\% \mathrm{Ni}$ & 4.7 & 99.6 & 6.6 & 2.4 & - \\
\hline 7.5 vol. $\% \mathrm{Ni}$ & 6.7 & 98.7 & 4.6 & 2.6 & - \\
\hline 10 vol. $\% \mathrm{Ni}$ & 8.7 & 99.1 & 4.4 & 2.9 & - \\
\hline 12.5 vol. $\% \mathrm{Ni}$ & 10.8 & 97.6 & 4.3 & 3.7 & - \\
\hline 15 vol. $\% \mathrm{Ni}$ & 12.9 & 98.1 & 3.8 & 4.9 & - \\
\hline 5 vol. $\% \mathrm{t}-\mathrm{ZrO}_{2}+5$ vol. $\% \mathrm{Ni}$ & 4.7 & 99.7 & 1.9 & 2.3 & 0.35 \\
\hline 7.5 vol. $\%$ t $-\mathrm{ZrO}_{2}+7.5$ vol. $\% \mathrm{Ni}$ & 6.7 & 99.2 & 1.8 & 2.8 & 0.29 \\
\hline 10 vol. $\% \mathrm{t}-\mathrm{ZrO}_{2}+10$ vol. $\% \mathrm{Ni}$ & 8.8 & 98.6 & 1.6 & 3.6 & 0.32 \\
\hline 12.5 vol. $\% \mathrm{t}-\mathrm{ZrO}_{2}+12.5$ vol. $\% \mathrm{Ni}$ & 11.3 & 98.8 & 1.5 & 4.3 & 0.33 \\
\hline 2.5 vol. $\% \mathrm{~m}-\mathrm{ZrO}_{2}+2.5$ vol. $\% \mathrm{Ni}$ & 2.4 & 99.0 & 3.0 & 5.6 & 0.44 \\
\hline 5 vol. $\%$ m- $-\mathrm{ZrO}_{2}+5$ vol. $\% \mathrm{Ni}$ & 4.5 & 98.7 & 2.5 & 7.1 & 0.45 \\
\hline 7.5 vol. $\% \mathrm{~m}-\mathrm{ZrO}_{2}+7.5$ vol. $\% \mathrm{Ni}$ & 6.9 & 99.1 & 1.9 & 6.3 & 0.48 \\
\hline 10 vol. $\% \mathrm{~m}-\mathrm{ZrO}_{2}+10$ vol. $\% \mathrm{Ni}$ & 7.9 & 98.5 & 1.8 & 5.5 & 0.59 \\
\hline 12.5 vol. $\% \mathrm{~m}-\mathrm{ZrO}_{2}+12.5$ vol. $\% \mathrm{Ni}$ & 10.8 & 97.8 & 1.9 & 7.1 & 0.65 \\
\hline
\end{tabular}


specimen was oxidized only once to avoid any thermal shock effect. The extent of oxidation, weight gain hereafter, was expressed by the weight change per unit area.

Phase identification was performed by X-ray diffractometry (XRD) with $\mathrm{Cu} K \alpha$ radiation. To observe the cross-sections, the specimen was first mounted within a resin, then ground with diamond paste to $3 \mu \mathrm{m}$ and polished with silica suspension to $0.05 \mu \mathrm{m}$. Care was taken to avoid tensile stress applied on the oxidized surface during grinding and polishing.

\section{Results and discussion}

\subsection{Toughness of the $\mathrm{Al}_{2} \mathrm{O}_{3} / \mathrm{ZrO}_{2} / \mathrm{Ni}$ composites}

Fig. 1 shows a typical micrograph of an $\mathrm{Al}_{2} \mathrm{O}_{3} / \mathrm{ZrO}_{2} /$ $\mathrm{Ni}$ composite. Both $\mathrm{ZrO}_{2}$ and $\mathrm{Ni}$ inclusions distributed uniformly within the $\mathrm{Al}_{2} \mathrm{O}_{3}$ matrix. The large $\mathrm{Ni}$ particles seems to isolate from each other within the matrix; it has also been confirmed by their high electrical resistivity. Table 1 shows the density and microstructural features of the composites. The data for the $\mathrm{Al}_{2} \mathrm{O}_{3} / \mathrm{Ni}$ composites are also shown for comparison. The density of the composites is higher than $97.5 \%$, indicating that dense $\mathrm{Al}_{2} \mathrm{O}_{3} / \mathrm{ZrO}_{2} / \mathrm{Ni}$ composites can be prepared by pressureless sintering at $1600{ }^{\circ} \mathrm{C}$ for $1 \mathrm{~h}$. The presence of both $\mathrm{ZrO}_{2}$ and $\mathrm{Ni}$ inclusions prohibits the coarsening of $\mathrm{Al}_{2} \mathrm{O}_{3}$ matrix during sintering; the microstructure of $\mathrm{Al}_{2} \mathrm{O}_{3}$ is thus refined. The $\mathrm{Ni}$ inclusions increase in their size with the increase of $\mathrm{Ni}$ content; nonetheless, the size of $\mathrm{ZrO}_{2}$ particles remains almost the same.

Fig. 2 shows the toughness of the $\mathrm{Al}_{2} \mathrm{O}_{3} / \mathrm{ZrO}_{2} / \mathrm{Ni}$ composites as a function of total inclusion content. The values for the $\mathrm{Al}_{2} \mathrm{O}_{3} / \mathrm{Ni}$ composites are also shown in the figure. The toughness of all the composites is higher than that of $\mathrm{Al}_{2} \mathrm{O}_{3}$ alone. Furthermore, the toughness of the $\mathrm{Al}_{2} \mathrm{O}_{3} / \mathrm{t}-\mathrm{ZrO}_{2} / \mathrm{Ni}$ composites is higher than that of

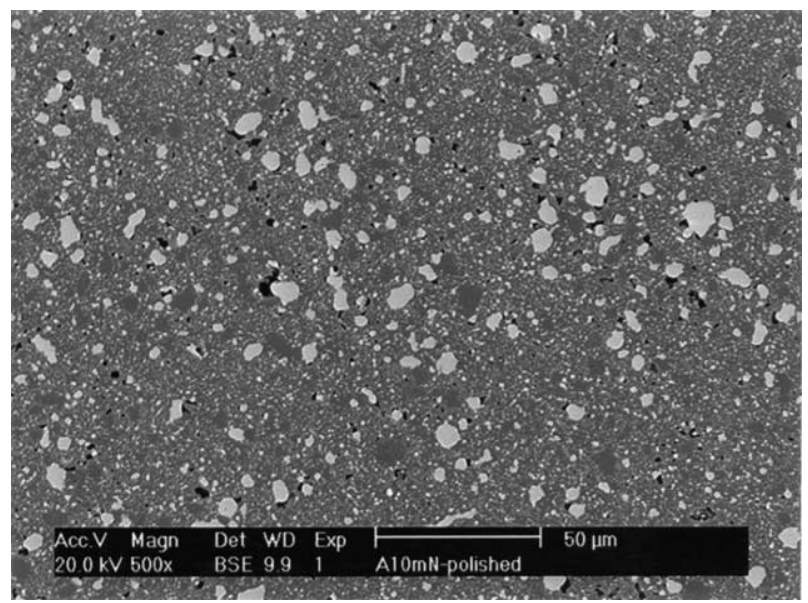

Fig. 1. SEM micrograph of an $\mathrm{Al}_{2} \mathrm{O}_{3} / 10 \% \mathrm{~m}-\mathrm{ZrO}_{2} / 10 \% \mathrm{Ni}$ composite. The large bright particles are $\mathrm{Ni}$ and small bright ones $\mathrm{ZrO}_{2}$.
$\mathrm{Al}_{2} \mathrm{O}_{3} / \mathrm{m}-\mathrm{ZrO}_{2} / \mathrm{Ni}$ and $\mathrm{Al}_{2} \mathrm{O}_{3} / \mathrm{Ni}$ composites. The active toughening mechanisms involved in the fracturing of the $\mathrm{Al}_{2} \mathrm{O}_{3} / \mathrm{t}-\mathrm{ZrO}_{2} / \mathrm{Ni}$ composites are transformation toughening and plastic deformation. ${ }^{5}$ These two mechanisms can interact with each other to bring in extra toughness enhancement. ${ }^{6}$ The toughness of the $\mathrm{Al}_{2} \mathrm{O}_{3} / \mathrm{m}-\mathrm{ZrO}_{2} / \mathrm{Ni}$ composites is higher than that of $\mathrm{Al}_{2} \mathrm{O}_{3} / \mathrm{Ni}$ composite only when the total inclusion content is low. It may indicate that the toughening mechanisms involved, microcracking and plastic deformation, in the $\mathrm{Al}_{2} \mathrm{O}_{3} / \mathrm{m}-\mathrm{ZrO}_{2} / \mathrm{Ni}$ composites affect each other in a negative manner. Detailed analysis can be found elsewhere. ${ }^{9}$

\subsection{Oxidation of $\mathrm{Al}_{2} \mathrm{O}_{3} / \mathrm{Ni}$ composites}

Fig. 3 shows the XRD pattern of a sintered $\mathrm{Al}_{2} \mathrm{O}_{3} / \mathrm{Ni}$ composite, nickel oxide is fully reduced into nickel after sintering. The electrical resistivity of the composites is higher than $10^{10} \Omega-\mathrm{cm}$, indicating that the Ni inclusions are isolated from each other. The XRD patterns of the oxidized composites are also shown in the figure. Both $\mathrm{NiO}$ and $\mathrm{NiAl}_{2} \mathrm{O}_{4}$ are formed on the surface after being

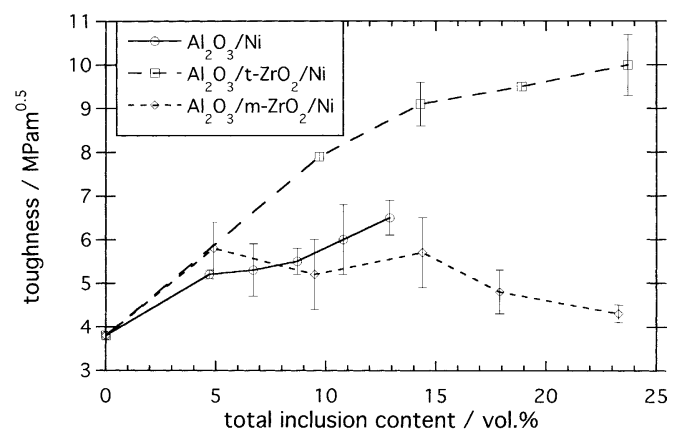

Fig. 2. Fracture toughness of $\mathrm{Al}_{2} \mathrm{O}_{3} / \mathrm{Ni}, \mathrm{Al}_{2} \mathrm{O}_{3} / t-\mathrm{ZrO}_{2} / \mathrm{Ni}$ and $\mathrm{Al}_{2} \mathrm{O}_{3} /$ $\mathrm{m}-\mathrm{ZrO}_{2} / \mathrm{Ni}$ composites as function of total inclusion content.

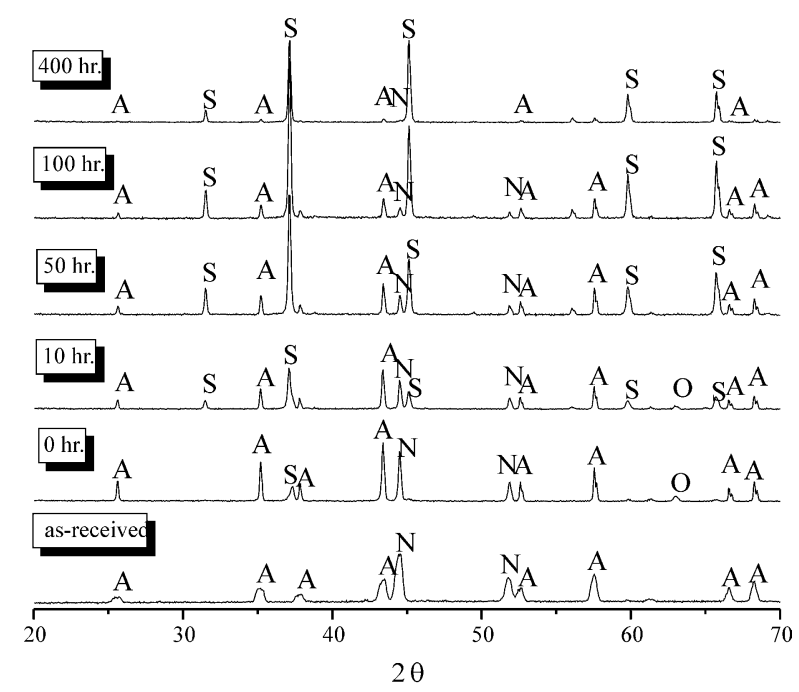

Fig. 3. XRD patterns of the as-sintered and oxidized $\mathrm{Al}_{2} \mathrm{O}_{3} / 12.5 \% \mathrm{Ni}$ composites $\left(\mathrm{A}=\mathrm{Al}_{2} \mathrm{O}_{3}, \mathrm{~N}=\mathrm{Ni}, \mathrm{O}=\mathrm{NiO}, \mathrm{S}=\mathrm{NiAl}_{2} \mathrm{O}_{4}\right)$. 
heated to $1200{ }^{\circ} \mathrm{C}$ (without dwell). $\mathrm{NiO}$ disappeared from the surface after oxidation for $10 \mathrm{~h}$; nonetheless, the amount of $\mathrm{NiAl}_{2} \mathrm{O}_{4}$ increases with increase in oxidation time. The phase analysis suggests that the following reactions took place during oxidation. The nickel inclusions first react with oxygen gas to form nickel oxide, as

$$
2 \mathrm{Ni}_{(\mathrm{s})}+\mathrm{O}_{2(\mathrm{~g})}=2 \mathrm{NiO}_{(\mathrm{s})} \text {. }
$$

Then, $\mathrm{NiO}$ is consumed with $\mathrm{Al}_{2} \mathrm{O}_{3}$ to form $\mathrm{NiAl}_{2} \mathrm{O}_{4}$, as

$\mathrm{NiO}_{(\mathrm{s})}+\mathrm{Al}_{3(\mathrm{~s})}=\mathrm{NiAl}_{2} \mathrm{O}_{4(\mathrm{~s})}$.

Fig. 4 shows the square of weight gain as a function of oxidation time at $1200{ }^{\circ} \mathrm{C}$. The square of weight gain exhibits linear relationships with oxidation time in the figure. Such linear relationship has also been reported in a previous study on the oxidation of $\mathrm{Ni}$-toughened $\mathrm{Al}_{2} \mathrm{O}_{3},{ }^{4}$ it suggests that the oxidation involves diffusion. The oxidation rate constant can be calculated from the slopes of the straight lines shown in Fig. 4. Fig. 5 shows the oxidation rate constant as a function of nickel content. The oxidation rate constant increases with the increase of $\mathrm{Ni}$ content; for example, the rate constant increases from $7.9 \times 10^{-12}$ to $3.5 \times 10^{-10} \mathrm{mg}^{2} /\left(\mathrm{mm}^{4} \mathrm{~s}\right)$ as $\mathrm{Ni}$ content increases from 4.7 to $12.9 \mathrm{vol} . \%$.

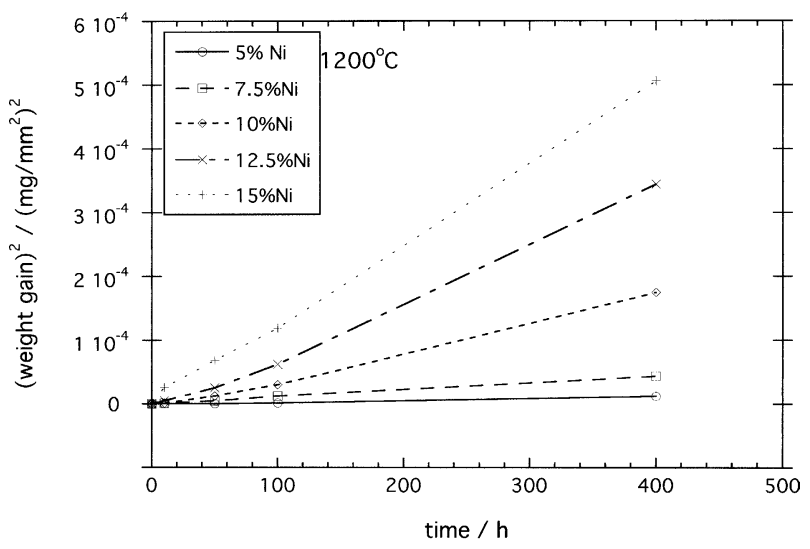

Fig. 4. Square of weight gain for $\mathrm{Al}_{2} \mathrm{O}_{3} / \mathrm{Ni}$ composites as function of oxidation time at $1200^{\circ} \mathrm{C}$.

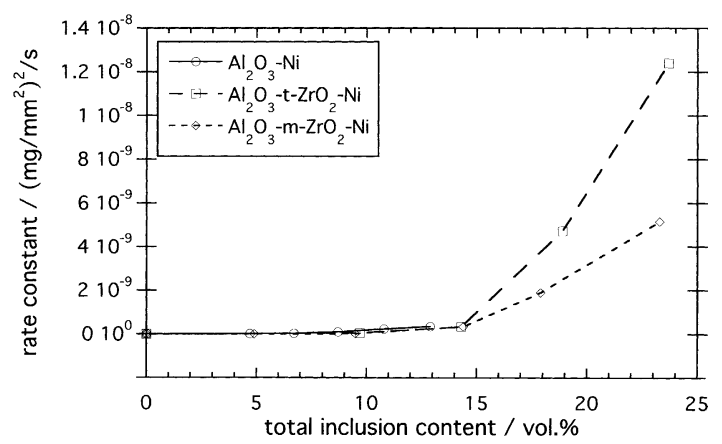

Fig. 5. Oxidation rate constant as function of total inclusion content. The oxidation temperature was $1200^{\circ} \mathrm{C}$.
Fig. 6 shows the microstructure of the cross-section of an oxidized composite. In the micrograph, the dark phase is alumina, the gray one is spinel and the bright one is nickel. The oxidation of nickel inclusions can be found only in the surface region with a thickness of around $80 \mu \mathrm{m}$. The formation of $\mathrm{NiAl}_{2} \mathrm{O}_{4}$ from $\mathrm{Ni}$ and $\mathrm{Al}_{2} \mathrm{O}_{3}$ involves a volume expansion of $11 \%$. Therefore, $\mathrm{NiAl}_{2} \mathrm{O}_{4}$ spinel occupies most of the surface region. Furthermore, the nickel ions can diffuse out from the internal $\mathrm{Ni}$ inclusion to the external surface, ${ }^{4}$ a dense surface layer comprising only $\mathrm{NiAl}_{2} \mathrm{O}_{4}$ spinel is formed after oxidation. Since oxygen ions have to travel through the alumina and spinel before reaching $\mathrm{Ni}$, the oxidation is therefore controlled by the diffusion of oxygen through the alumina and $\mathrm{NiAl}_{2} \mathrm{O}_{4}$ spinel, as suggested by Wang et al. ${ }^{4}$

\subsection{Oxidation of $\mathrm{Al}_{2} \mathrm{O}_{3} / \mathrm{t}-\mathrm{ZrO}_{2} / \mathrm{Ni}$ composites}

Fig. 7 shows the XRD patterns of sintered $\mathrm{Al}_{2} \mathrm{O}_{3} / \mathrm{t}$ $\mathrm{ZrO}_{2} / \mathrm{Ni}$ composites. Apart from $\alpha-\mathrm{Al}_{2} \mathrm{O}_{3}$ and cubic-Ni, $\mathrm{ZrO}_{2}$ is mainly in its tetragonal form. The electrical resistivity of the composites is higher than $10^{11} \Omega$-cm, indicating that the $\mathrm{Ni}$ inclusions are also isolated from each other within the $\mathrm{Al}_{2} \mathrm{O}_{3} / t-\mathrm{ZrO}_{2}$ matrix. Unlike the $\mathrm{Al}_{2} \mathrm{O}_{3} / \mathrm{Ni}$ composites, the size of $\mathrm{Ni}$ inclusions in the $\mathrm{Al}_{2} \mathrm{O}_{3} / \mathrm{t}-\mathrm{ZrO}_{2} / \mathrm{Ni}$ composites is larger than that of the $\mathrm{Al}_{2} \mathrm{O}_{3}$ matrix. It may be because the fine $\mathrm{ZrO}_{2}$ particles act as a buffer layer for the milling of nickel oxide particles; ${ }^{10}$ thus decreasing the milling efficiency on nickel oxide particles.

Both $\mathrm{NiO}$ and $\mathrm{NiAl}_{2} \mathrm{O}_{4}$ are present on the surface of oxidized composite when the oxidation time is zero (Fig. 7). The amount of $\mathrm{NiAl}_{2} \mathrm{O}_{4}$ increases with increasing oxidation time, while the amount of $\mathrm{NiO}$ shows the reverse trend. However, $\mathrm{NiO}$ remains on the surface region till $400 \mathrm{~h}$ at $1200{ }^{\circ} \mathrm{C} . \mathrm{ZrO}_{2}$ maintains its

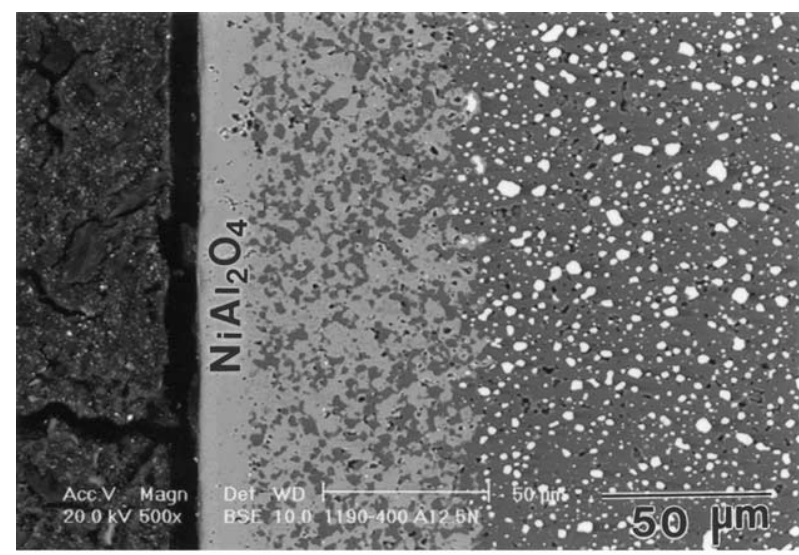

Fig. 6. SEM micrograph of an oxidized $\mathrm{Al}_{2} \mathrm{O}_{3} / 12.5 \% \mathrm{Ni}$ composite. The oxidation is carried out at $1200{ }^{\circ} \mathrm{C}$ for $400 \mathrm{~h}$. The dark phase is $\mathrm{Al}_{2} \mathrm{O}_{3}$, gray phase $\mathrm{NiAl}_{2} \mathrm{O}_{4}$ and bright phase $\mathrm{Ni}$. 
t-phase throughout the oxidation process, indicating that $\mathrm{ZrO}_{2}$ is inert with respect to the oxidation reactions.

Fig. 8 shows the square of weight gain as a function of oxidation time. Similar to the oxidation of $\mathrm{Al}_{2} \mathrm{O}_{3} / \mathrm{Ni}$ composites, linear relationships are also exhibited between the square of weight gain and oxidation time. It suggests that the oxidation of $\mathrm{Al}_{2} \mathrm{O}_{3} / \mathrm{t}-\mathrm{ZrO}_{2} / \mathrm{Ni}$ composites involves diffusion. Fig. 5 shows the oxidation rate constant of the composites as a function of total inclusion content. The rate constant jumps when the total inclusion content is higher than 14.2 vol. \%, with the $\mathrm{Ni}$ content being 6.7 vol. $\%$ and the $\mathrm{t}-\mathrm{ZrO}_{2}$ content 7.5 vol.\% (Table 1). As demonstrated by the microstructure observation and electrical resistance measurement, the $\mathrm{Ni}$ inclusions are isolated particles within the $\mathrm{Al}_{2} \mathrm{O}_{3} / \mathrm{t}$ $\mathrm{ZrO}_{2}$ matrix. The oxidation rate constant increases from $3.3 \times 10^{-10}$ to $4.7 \times 10^{-9} \mathrm{mg}^{2} /\left(\mathrm{mm}^{4} \mathrm{~s}\right)$, namely 1 order of magnitude, when the $\mathrm{Ni}$ content increases from 6.7 to 8.8 vol. $\%, \mathrm{ZrO}_{2}$ content from 7.5 to $10 \%$, However, for the $\mathrm{Al}_{2} \mathrm{O}_{3} / \mathrm{Ni}$ composites, the oxidation rate constant increases from $3.1 \times 10^{-11}$ to $9.1 \times 10^{-11} \mathrm{mg}^{2} /$ $\left(\mathrm{mm}^{4} \mathrm{~s}\right)$ when the $\mathrm{Ni}$ content increases from 6.7 to 8.7

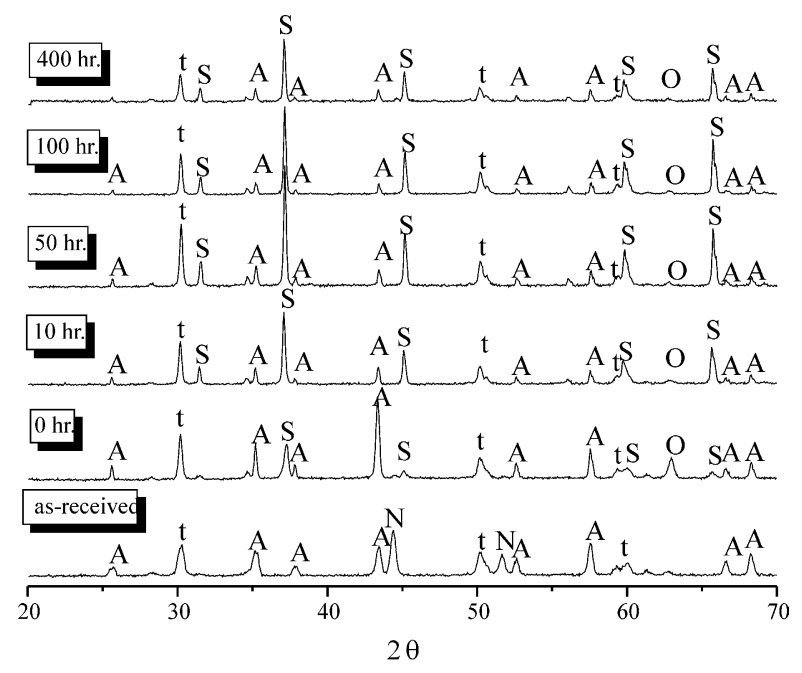

Fig. 7. XRD patterns of the as-sintered and oxidized $\mathrm{Al}_{2} \mathrm{O}_{3} / 12.5 \% \mathrm{t}$ $\mathrm{ZrO}_{2} / 12.5 \% \mathrm{Ni}$ composites $\left(\mathrm{t}=\mathrm{t}-\mathrm{ZrO}_{2}\right)$.

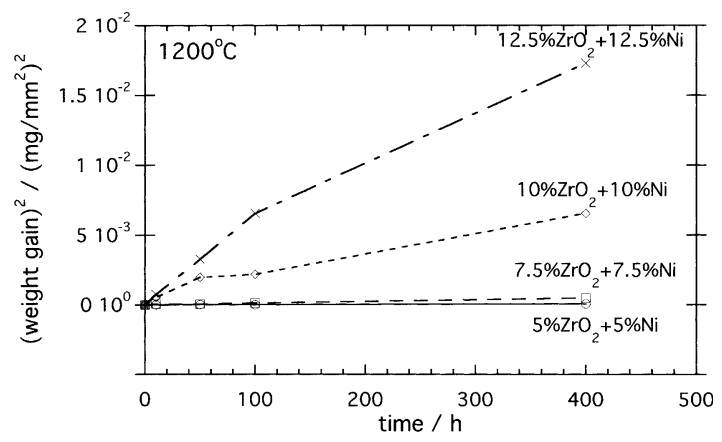

Fig. 8. Square of weight gain of $\mathrm{Al}_{2} \mathrm{O}_{3} / \mathrm{t}-\mathrm{ZrO}_{2} / \mathrm{Ni}$ composites as function of oxidation time at $1200{ }^{\circ} \mathrm{C}$. vol. \%. It indicates that the significant increase of the oxidation rate for the $\mathrm{Al}_{2} \mathrm{O}_{3} / \mathrm{t}-\mathrm{ZrO}_{2} / \mathrm{Ni}$ composite from the total inclusion content of 14.2 vol. \% is mainly contributed from the increase in $\mathrm{ZrO}_{2}$ content. Since zirconia is a good oxygen conductor, it thus implies that $\mathrm{ZrO}_{2}$ inclusions form a continuous network when the $\mathrm{ZrO}_{2}$ content is higher than 10 vol.\%. For the system of two components with equal size, the percolation threshold is 16 vol.\%. ${ }^{11}$ However, the percolation threshold decreases with increasing size ratio between the two components. ${ }^{11}$ The size of $\mathrm{ZrO}_{2}$ inclusions after sintering is in the range of $0.3-0.7 \mu \mathrm{m}$ (Table 1), which is smaller than that of $\mathrm{Al}_{2} \mathrm{O}_{3}$ and $\mathrm{Ni}, 10$ vol. $\%$ of $\mathrm{t}-\mathrm{ZrO}_{2}$ inclusions can thus reach the percolation threshold within the $\mathrm{Al}_{2} \mathrm{O}_{3} / \mathrm{Ni}$ matrix.

Fig. 9(a) shows the microstructure of the cross-section of an oxidized $\mathrm{Al}_{2} \mathrm{O}_{3} / \mathrm{t}-\mathrm{ZrO}_{2} / \mathrm{Ni}$ composite. The thickness of the oxidation zone is around $1000 \mu \mathrm{m}$ after oxidation at $1200{ }^{\circ} \mathrm{C}$ for $400 \mathrm{~h}$. There is no dense $\mathrm{NiAl}_{2} \mathrm{O}_{4}$ surface layer observed. An enlarged micrograph of the oxidized region is shown in Fig. 9(b). The large bright particles are $\mathrm{Ni}$ and the small bright ones are $\mathrm{ZrO}_{2}$.

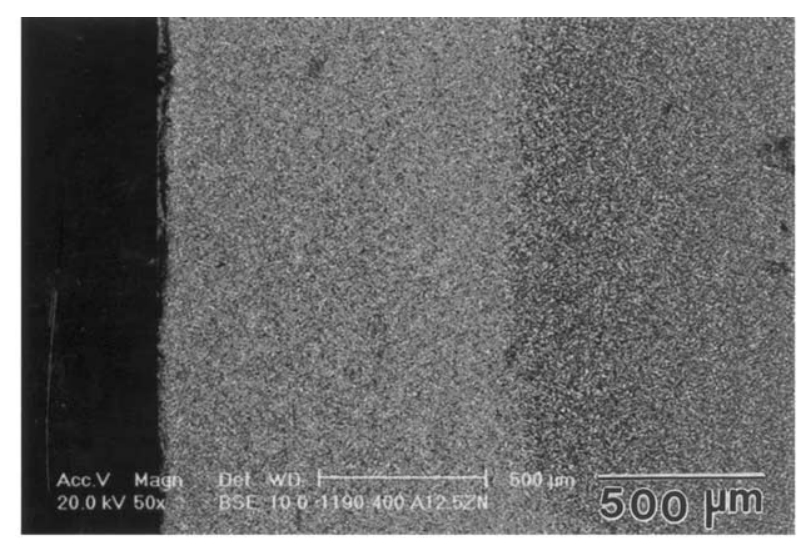

(a)

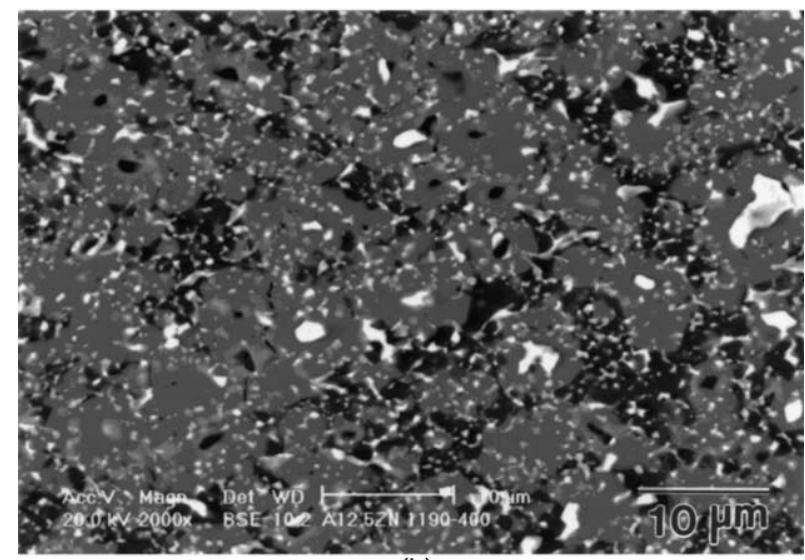

(b)

Fig. 9. (a) $\mathrm{SEM}$ micrograph of an $\mathrm{Al}_{2} \mathrm{O}_{3} / 12.5 \% \mathrm{t}-\mathrm{ZrO}_{2} / 12.5 \% \mathrm{Ni}$ composite after oxidation at $1200{ }^{\circ} \mathrm{C}$ for $400 \mathrm{~h}$. The dark phase in (b) is $\mathrm{Al}_{2} \mathrm{O}_{3}$, gray phase $\mathrm{NiAl}_{2} \mathrm{O}_{4}$, large bright particles $\mathrm{Ni}$ and small bright particles $\mathrm{ZrO}_{2}$. 
$\mathrm{NiAl}_{2} \mathrm{O}_{4}$ (the gray phase) is found to surround each $\mathrm{Ni}$ inclusion in the oxidation region. From the microstructural observation, the oxygen ions can travel a distance of $1000 \mu \mathrm{m}$ into the composite to react with $\mathrm{Ni}$ forming $\mathrm{NiAl}_{2} \mathrm{O}_{4}$. However, residual $\mathrm{Ni}$ remains in the oxidation zone. The crystal structure of $\mathrm{NiAl}_{2} \mathrm{O}_{4}$ is very similar to that of $\mathrm{Al}_{2} \mathrm{O}_{3}$ in terms of oxygen packing. ${ }^{12}$ Thus, the diffusion of oxygen in the $\mathrm{NiAl}_{2} \mathrm{O}_{4}$ lattice may be as slow as that in the $\mathrm{Al}_{2} \mathrm{O}_{3}$ lattice. Therefore, the $\mathrm{Ni}$ inclusions are well protected once dense $\mathrm{NiAl}_{2} \mathrm{O}_{4}$ interface is formed.

\subsection{Oxidation of $\mathrm{Al}_{2} \mathrm{O}_{3} / \mathrm{m}-\mathrm{ZrO} \mathrm{O}_{2} / \mathrm{Ni}$ composites}

Fig. 10 shows the XRD pattern of the as-sintered $\mathrm{Al}_{2} \mathrm{O}_{3} / \mathrm{m}-\mathrm{ZrO}_{2} / \mathrm{Ni}$ composite. Apart from $\mathrm{Al}_{2} \mathrm{O}_{3}$ and $\mathrm{Ni}$, both $\mathrm{t}$ - and $\mathrm{m}-\mathrm{ZrO}_{2}$ are detected. The zirconia inclusions are constrained within the $\mathrm{Al}_{2} \mathrm{O}_{3} / \mathrm{Ni}$ matrix, the transformation of some zirconia inclusions from $\mathrm{t}$ to $\mathrm{m}$ may thus be suppressed during cooling from sintering temperature. The electrical resistivity measurement indicates that the $\mathrm{Ni}$ inclusions are isolated from each other in the composites.

Similar to that of $\mathrm{Al}_{2} \mathrm{O}_{3} / \mathrm{t}-\mathrm{ZrO}_{2} / \mathrm{Ni}$ composites, the size of $\mathrm{Ni}$ inclusions in the $\mathrm{Al}_{2} \mathrm{O}_{3} / \mathrm{m}-\mathrm{ZrO}_{2} / \mathrm{Ni}$ composites is larger than that of the $\mathrm{Al}_{2} \mathrm{O}_{3}$ matrix grains. The size of $\mathrm{m}-\mathrm{ZrO}_{2}$ powder is smaller than that of $\mathrm{t}-\mathrm{ZrO}_{2}$ powder as demonstrated by the value of specific surface area. Fine $\mathrm{m}-\mathrm{ZrO}_{2}$ powder acts as an effective buffer layer for the milling of nickel oxide particles; ${ }^{10}$ the resulting size of $\mathrm{Ni}$ inclusions after sintering is therefore large. The fine $\mathrm{ZrO}_{2}$ particles can also combine with each other to form larger $\mathrm{ZrO}_{2}$ inclusions after sintering (Table 1).

$\mathrm{NiO}$ and $\mathrm{NiAl}_{2} \mathrm{O}_{4}$ first appeared on the surface of the oxidized specimen when the specimen was heated to

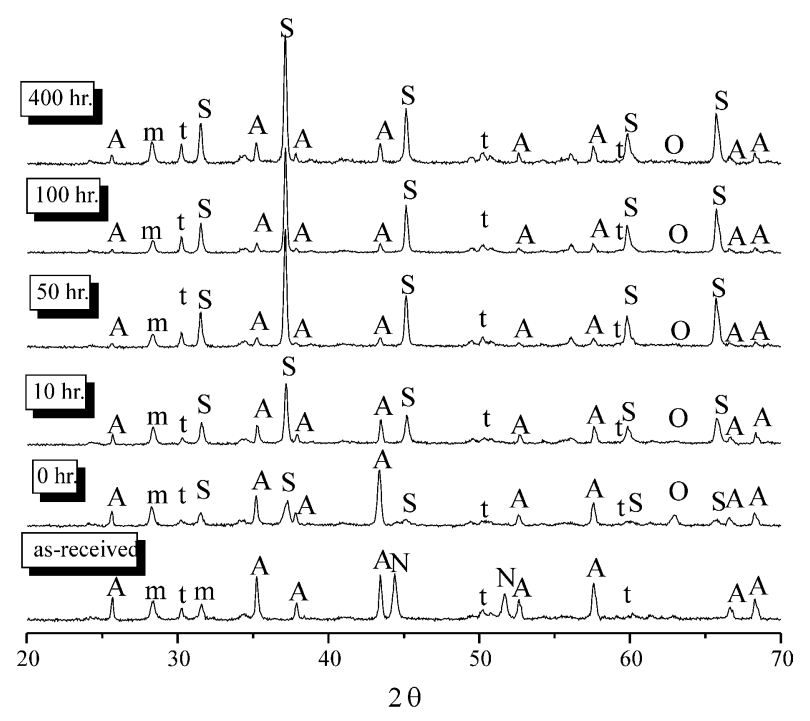

Fig. 10. XRD patterns of the as-sintered and oxidized $\mathrm{Al}_{2} \mathrm{O}_{3}$ / $12.5 \% \mathrm{~m}-\mathrm{ZrO}_{2} / 12.5 \% \mathrm{Ni}$ composite $\left(\mathrm{m}=\mathrm{m}-\mathrm{ZrO}_{2}\right)$.
$1200{ }^{\circ} \mathrm{C}$ without dwell. Ni disappears from the surface at the beginning of oxidation, while $\mathrm{NiO}$ remains throughout the oxidation treatment. The intensity of $\mathrm{NiAl}_{2} \mathrm{O}_{4}$ increases with increasing oxidation time. Zirconia remains, in terms of phase and amount, almost the same throughout the oxidation, indicating that zirconia is inert chemically to all the oxidation products, such as $\mathrm{NiO}$ and $\mathrm{NiAl}_{2} \mathrm{O}_{4}$.

Fig. 11 shows the square of weight gain of the $\mathrm{Al}_{2} \mathrm{O}_{3} /$ $\mathrm{m}-\mathrm{ZrO}_{2} / \mathrm{Ni}$ composites as a function of oxidation time. The parabolic relationship between weight gain and time indicates that the oxidation of the $\mathrm{Al}_{2} \mathrm{O}_{3} / \mathrm{m}-\mathrm{ZrO}_{2} /$ $\mathrm{Ni}$ composites at $1200{ }^{\circ} \mathrm{C}$ may also involves diffusion. As shown in Fig. 5, the oxidation rate constant also jumps when the total inclusion content is higher than 14.4 vol. $\%\left(\mathrm{Ni}=6.9\right.$ vol. $\%, \mathrm{~m}-\mathrm{ZrO}_{2}=7.5$ vol. $\left.\%\right)$, indicating that 10 vol. $\%$ fine $\mathrm{m}-\mathrm{ZrO}_{2}$ inclusions form interconnected network for oxygen transportation.

Fig. 12 shows the cross-section of an oxidized $\mathrm{Al}_{2} \mathrm{O}_{3} /$ $\mathrm{m}-\mathrm{ZrO}_{2} / \mathrm{Ni}$ composite. The large bright particles are $\mathrm{Ni}$ and the small bright ones are $\mathrm{ZrO}_{2}$. The thickness of the oxidation zone is around $450 \mu \mathrm{m}$, as shown in Fig. 12(a). No dense $\mathrm{NiAl}_{2} \mathrm{O}_{4}$ surface layer is observed; $\mathrm{NiAl}_{2} \mathrm{O}_{4}$ (the gray phase) is located at the $\mathrm{Al}_{2} \mathrm{O}_{3} / \mathrm{Ni}$ interface instead, as seen in Fig. 12(b).

\subsection{Comparison}

The oxidation rate constants of the $\mathrm{Al}_{2} \mathrm{O}_{3} / \mathrm{t}-\mathrm{ZrO}_{2} / \mathrm{Ni}$ and $\mathrm{Al}_{2} \mathrm{O}_{3} / \mathrm{m}-\mathrm{ZrO}_{2} / \mathrm{Ni}$ composites are low when the $\mathrm{ZrO}_{2}$ content is lower than 10 vol.\% (Fig. 5). However, the oxidation kinetics speed up when the $\mathrm{ZrO}_{2}$ content is higher than $10 \mathrm{vol} . \%$. The thickness of the oxidation zone for the $\mathrm{Al}_{2} \mathrm{O}_{3} / 12.5 \% \mathrm{Ni}, \quad \mathrm{Al}_{2} \mathrm{O}_{3} / 12.5 \% \mathrm{t}-\mathrm{ZrO}_{2} /$ $12.5 \% \mathrm{Ni}$ and $\mathrm{Al}_{2} \mathrm{O}_{3} / 12.5 \% \mathrm{~m}-\mathrm{ZrO}_{2} / 12.5 \% \mathrm{Ni}$ composites is 80,1000 and $450 \mu \mathrm{m}$ after oxidation at $1200{ }^{\circ} \mathrm{C}$ for $400 \mathrm{~h}$, respectively. The diffusivity of oxygen in zirconia is about $10^{-6}-10^{-8} \mathrm{~cm}^{2} / \mathrm{s}$ and in alumina about $10^{-16}-10^{-20} \mathrm{~cm}^{2} / \mathrm{s}$ at the oxidation temperature, ${ }^{13}$ the interconnection of $\mathrm{ZrO}_{2}$ particles thus provides a fast path for oxygen transportation.

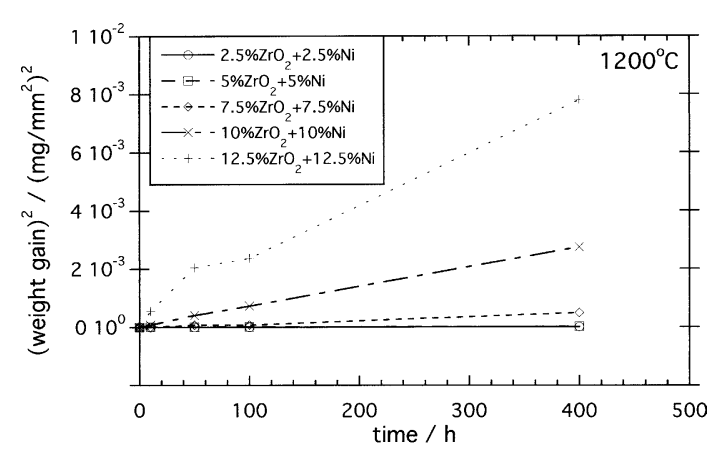

Fig. 11. Square of weight gain of $\mathrm{Al}_{2} \mathrm{O}_{3} / \mathrm{m}-\mathrm{ZrO}_{2} / \mathrm{Ni}$ composites as function of oxidation time at $1200{ }^{\circ} \mathrm{C}$. 
The microstructure of the oxidized region also depends on the amount of zirconia. There are two oxidation modes in terms of the microstructural features of oxidized composites. ${ }^{14}$ The mode I microstructure features a thin and dense oxidation surface layer, as demonstrated in Fig. 6; while the mode II microstructure shows a thick oxidation zone without a dense surface layer, as demonstrated in Figs. 9(a) and 12(a). The different mode is mainly affected by the diffusion rate in the matrix. A fast matrix diffusion rate results in mode II microstructure, while a slow one yields mode I microstructure. In the present study, the microstructural feature of the oxidized composites is manipulated by increasing the $\mathrm{ZrO}_{2}$ content. In other words, the mode I oxidation behavior is swapped to mode II by adding more than 10 vol. $\% \mathrm{ZrO}_{2}$. It demonstrates that the $\mathrm{ZrO}_{2}$ content has a significant impact on oxidation behavior.

The toughness enhancement by adding $\mathrm{ZrO}_{2}$ into $\mathrm{Al}_{2} \mathrm{O}_{3} / \mathrm{Ni}$ composites is traded off by the decrease in oxidation resistance. Though the toughness of $\mathrm{Al}_{2} \mathrm{O}_{3} / \mathrm{Ni}$ matrix can be enhanced to a value as high as $10 \mathrm{MPa}$ $\mathrm{m}^{0.5}$ by adding higher amount of $\mathrm{t}-\mathrm{ZrO}_{2}$, the amount of

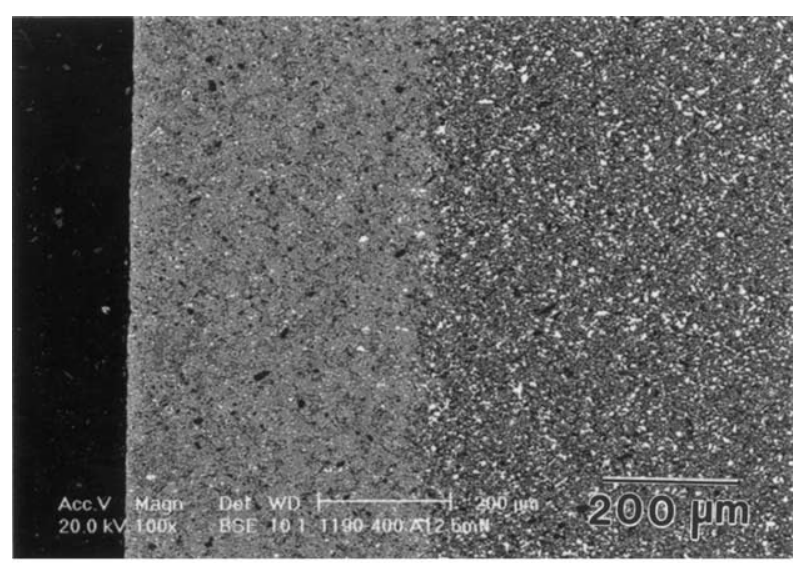

(a)

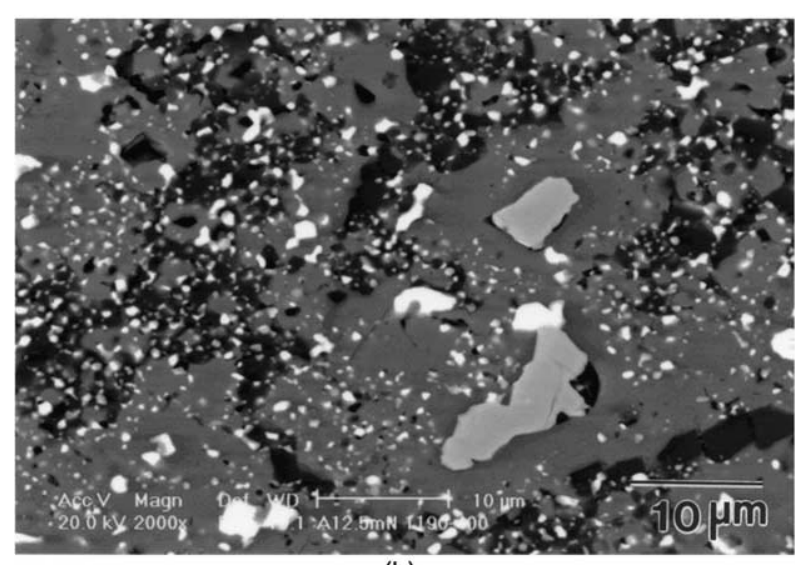

(b)

Fig. 12. (a) $\mathrm{SEM}$ micrograph of an $\mathrm{Al}_{2} \mathrm{O}_{3} / 12.5 \% \mathrm{~m}-\mathrm{ZrO}_{2} / 12.5 \% \mathrm{~N}$ composite after oxidation at $1200{ }^{\circ} \mathrm{C}$ for $400 \mathrm{~h}$. The dark phase in (b) is $\mathrm{Al}_{2} \mathrm{O}_{3}$, gray phase $\mathrm{NiAl}_{2} \mathrm{O}_{4}$, large bright particles $\mathrm{Ni}$ and small bright particles $\mathrm{ZrO}_{2}$.
$\mathrm{t}-\mathrm{ZrO}_{2}$ has to be lower than $10 \mathrm{vol} . \%$, as long as a hightemperature performance is of major concern. From Fig. 2, the toughness of the $\mathrm{Al}_{2} \mathrm{O}_{3} / \mathrm{t}-\mathrm{ZrO}_{2} / \mathrm{Ni}$ composite with $\mathrm{ZrO}_{2}$ content lower than $10 \%$ can still reach a toughness of $9 \mathrm{MPa} \mathrm{m}^{0.5}$.

According to the microstructure observation, the formation of a dense $\mathrm{NiAl}_{2} \mathrm{O}_{4}$ surface layer has a significant influence on oxidation resistance. A dense $\mathrm{NiAl}_{2} \mathrm{O}_{4}$ surface layer can prevent the Ni-containing composites from quick oxidation (Fig. 6). Furthermore, $\mathrm{NiAl}_{2} \mathrm{O}_{4}$ at the $\mathrm{Al}_{2} \mathrm{O}_{3} / \mathrm{Ni}$ interface forms good protective layer for individual $\mathrm{Ni}$ inclusions [Figs. 9(b) and 12(b)]. It implies that the diffusion of oxygen in the $\mathrm{NiAl}_{2} \mathrm{O}_{4}$ spinel layer is slow. Wang et al. had suggested that the dominant oxidation mechanism for $\mathrm{Al}_{2} \mathrm{O}_{3} / \mathrm{Ni}$ composites at elevated temperatures is the diffusion of oxygen through $\mathrm{Al}_{2} \mathrm{O}_{3}$ and $\mathrm{NiAl}_{2} \mathrm{O}_{4}$ spinel. ${ }^{4}$ This mechanism may also dominate the oxidation of $\mathrm{Al}_{2} \mathrm{O}_{3} /$ $\mathrm{t}-\mathrm{ZrO}_{2} / \mathrm{Ni}$ and $\mathrm{Al}_{2} \mathrm{O}_{3} / \mathrm{m}-\mathrm{ZrO}_{2} / \mathrm{Ni}$ composites.

Though the toughness of $\mathrm{Al}_{2} \mathrm{O}_{3} / \mathrm{t}-\mathrm{ZrO}_{2} / \mathrm{Ni}$ composites is higher than that of $\mathrm{Al}_{2} \mathrm{O}_{3} / \mathrm{m}-\mathrm{ZrO}_{2} / \mathrm{Ni}$ composites (Fig. 2), the oxidation resistance of $\mathrm{Al}_{2} \mathrm{O}_{3} / \mathrm{m}-\mathrm{ZrO}_{2} / \mathrm{Ni}$ composites is slightly better (Fig. 5). There are $3 \mathrm{~mol} \%$ $\mathrm{Y}_{2} \mathrm{O}_{3}$ solute in the t-phase zirconia. The aliovalent cation dopants, especially the ones with larger ionic radii, generally can substitute for $\mathrm{Zr}$ ion, and creating oxygen vacancies for charge compensation. ${ }^{15}$ With the help of oxygen vacancies, the transportation of oxygen in the $\mathrm{t}-\mathrm{ZrO}_{2}$ network is therefore faster than that in the $\mathrm{m}-\mathrm{ZrO}_{2}$ network.

\section{Conclusions}

The addition of $\mathrm{t}-\mathrm{ZrO}_{2}$ particles can improve significantly the toughness of $\mathrm{Al}_{2} \mathrm{O}_{3} / \mathrm{Ni}$ composites. In the present study, the oxidation behavior of $\mathrm{Al}_{2} \mathrm{O}_{3} / \mathrm{Ni}$, $\mathrm{Al}_{2} \mathrm{O}_{3} / \mathrm{t}-\mathrm{ZrO}_{2} / \mathrm{Ni}$ and $\mathrm{Al}_{2} \mathrm{O}_{3} / \mathrm{m}-\mathrm{ZrO}_{2} / \mathrm{Ni}$ composites is investigated. Fine $\mathrm{ZrO}_{2}$ particles form interconnected network when the $\mathrm{ZrO}_{2}$ content is higher than the percolation threshold, 10 vol.\%. Oxygen can move fast along the $\mathrm{ZrO}_{2}$ network, the oxidation resistance of $\mathrm{Al}_{2} \mathrm{O}_{3} / \mathrm{Ni}$ composites is thus degraded significantly. Therefore, the amount of $\mathrm{ZrO}_{2}$ added into $\mathrm{Al}_{2} \mathrm{O}_{3} / \mathrm{Ni}$ composites has to be kept below the threshold limit. The amount of oxygen vacancies in $\mathrm{t}-\mathrm{ZrO}_{2}$ is higher than that in $\mathrm{m}-\mathrm{ZrO}_{2}$, thus the oxidation resistance of $\mathrm{Al}_{2} \mathrm{O}_{3} /$ $\mathrm{m}-\mathrm{ZrO}_{2} / \mathrm{Ni}$ composites is slightly better than that of $\mathrm{Al}_{2} \mathrm{O}_{3} / \mathrm{t}-\mathrm{ZrO}_{2} / \mathrm{Ni}$ composites.

\section{Acknowledgements}

The National Science Council, ROC, supported the present study through the contract number of NSC892216-E002-049. 


\section{References}

1. Sekino, T., Nakajima, T., Ueda, S. and Niihara, K., Reduction and sintering of a nickel-dispersed-alumina composite and its properties. J. Am. Ceram. Soc., 1997, 80, 1139-1148.

2. Fahrenholtz, W. G., Ellerby, D. T. and Loehman, R. E., $\mathrm{Al}_{2} \mathrm{O}_{3}-$ Ni composites with high strength and fracture toughness. J. Am. Ceram. Soc., 2000, 83, 1279-1280.

3. Tuan, W. H. and Brook, R. J., Processing of alumina/nickel composites. J. Eur. Ceram. Soc., 1992, 10, 95-100.

4. Wang, T. C., Chen, R. Z. and Tuan, W. H., Oxidation resistance of Ni-toughened $\mathrm{Al}_{2} \mathrm{O}_{3}$. J. Eur. Ceram. Soc., 2003, 23, 927-934.

5. Chen, R. Z., Chiu, Y. T. and Tuan, W. H., Toughening alumina with both nickel and zirconia inclusions. J. Eur. Ceram. Soc., 2000, 20, 1901-1906.

6. Tuan, W. H. and Chen, R., Z, Interactions between toughening mechanisms - transformation toughening vs. plastic deformation. J. Mater. Research, 2002, 17, 2921-2928.

7. Hannink, R. H. J., Kelly, P. M. and Muddle, B. C., Transformation toughening in zirconia-containing ceramics. J. Am. Ceram. Soc., 2000, 83, 461-487.

8. Claussen, N., Steeb, J. and Fabst, R. F., Effect of induced microcracking on the fracture toughness of ceramics. Am. Ceram. Soc. Bull., 1977, 56, 559-562.

9. Wang, T. C., Chen, R. Z. and Tuan, W. H., The addition of monoclinic $\mathrm{ZrO}_{2}$ on the mechanical properties of $\mathrm{Al}_{2} \mathrm{O}_{3} / \mathrm{Ni}$ composites (in preparation).

10. Wu, S., Gesing, A. J., Travitzky, N. A. and Claussen, N., Fabrication and properties of Al-infiltrated RBAO-based composites. J. Eur. Ceram. Soc., 1991, 7, 277-281.

11. McLachlan, D. S., Blaszkiewicz, M. and Newnham, R. E., Electrical resistivity of composites. J. Am. Ceram. Soc., 1990, 73, 2178-2203.

12. Simpson, Y. K., McKernan, S. and Carter, C. B., An alumina/ spinel interface. J. Am. Ceram. Soc., 1987, 70 (the back cover of July issue)

13. Aldebert, P. and Traverse, J. P., Structure and ionic mobility of zirconia at high temperature. J. Am. Ceram. Soc., 1985, 68, 34-40.

14. Lin, C., Zangvil, A. and Ruh, R., Mode of oxidation in SiCreinforced mullite $/ \mathrm{ZrO}_{2}$ composites: oxidation vs. depth behavior. Acta Mater., 1999, 47, 1977-1986.

15. Li, P., Chen, I.-W. and Penner-Hahn, J. E., Effect of dopants on zirconia stabilization - an X-ray absorption study: I, Trivalent dopants. J. Am. Ceram. Soc., 1994, 77, 118-128. 